\title{
UDC 631.527:635.52
}

\section{EVALUATION OF THE SEASON OF MUTAGENIC FACTORS TO CHANGE THE QUALITATIVE SIGNS, WHAT ARE DEFINING PHENOTYP OF LEAFS PLATE MUTANT PLANTS OF LEAF LETTUCE}

\section{Kondratenko S. I.}

Institute of vegetable and melon growing of National Academy of Agricultural Sciences of Ukraine Instytutska str., 1, vill. Selektsiine, Kharkiv rg., Ukraine, 62478

E-mail: ovoch.iob@gmail.com

https://doi.org/10.32717/0131-0062-2018-64-06-13

The aim of the research. To determine the effect of mutagenic factors on the formation of qualitative traits that determine the phenotype of the leaf blade and conduct a comparative correlation analysis between the manifestation of qualitative and quantitative traits of mutant leaf lettuce genotypes. Methods. Nonparametric statistics, field estimations, calculative and analytical ones. Results. The peculiarities of the physical and chemical mutagenesis effect on the phenotypic manifestation of qualitative traits that determine the leaf blade morphology of leaf lettuce ware ascertained. The degree of discrepancy in the manifestation of qualitative traits is determined depending on the effect of the mutagenic factor between the initial forms and the mutant genotypes derived from them. Based on the correlation analysis, important linkages between the qualitative and quantitative characteristics of the genotypes studied for the breeding process were established. The manifestation of the association of signs determining the phenotype of the leaf blade made it possible to distinguish two contrasting mutant samples in comparison with the original form ([Snizhinka (DMS, $6 \mathrm{~h}$ ), mf-1] $(\mathrm{K}-7392(1))\left(r_{s}=0,43\right)$ and [Snizhinka (7 kP)] $\left.(\mathrm{K}-7402)\left(r_{s}=0,31\right)\right)$. Conclusions. The studied correlation links make it possible to select highly productive genotypes of leaf lettuce in the early stages of plant ontogeny by association of qualitative traits that determine the phenotype of a leaf blade. Particularly useful is the established, statistically significant, correlation relationship between the integral indicator for the aggregate of qualitative characteristics "average index for the sample" and the level of quantitative traits "maximum leaf length" and "yield" $\left(r_{s}=-0.51 \ldots 0.49\right)$, which is important for identifying highly productive genotypes of leaf lettuce. Based on mutant samples of leaf lettuce, a new high-yielding cultivar Major ware created, which exceeded the grade-standard Snizhinka on a set of valuable quantitative traits. The yield of the new variety is $10.0 \mathrm{t} / \mathrm{h}$ a at $6.14 \mathrm{t} / \mathrm{ha}$ for the standard. The period from mass shoots to commercial ripeness in a new cultivar is 17 days, in a standard's cultivar Snizhinka up to 23 days.

Key words: leaf lettuce, leaf blade, qualitative traits, induced mutagenesis, correlation connections

\section{ОЦІНКА ПІСЛЯДІЇ МУТАГЕННИХ ЧИННИКІВ НА МІНЛИВІСТЬ ЯКІСНИХ ОЗНАК, ЩО ВИЗНАЧАЮТЬ ФЕНОТИП ЛИСТКОВОЇ ПЛАСТИНКИ МУТАНТНИХ РОСЛИН САЛАТУ ЛИСТКОВОГО}

\author{
Кондратенко С. I. \\ Інститут овочівництва і баштанництва НААН України \\ вул. Інститутська, 1, сел. Селекційне Харківської обл., Україна, 62478 \\ E-mail:ovoch.iob@gmail.com
}

Мета. Визначити дію мутагенних чинників на формування якісних ознак, які визначають фенотип листкової пластинки та провести порівняльний кореляційний аналіз між проявом якісних і кількісних ознак генотипів салату листкового мутантного походження. Методи. Непараметричної статистики, польової оцінки, розрахунково-аналітичні. Результати. Встановлено особливості дії фізичного і хімічного мутагенезу на фенотиповий прояв якісних ознак, що визначають морфологію листкової пластинки салату листкового. Визначено ступінь розбіжності прояву якісних ознак залежно від дії мутагенного чинника між вихідними формами і похідними від них мутантними генотипами. На основі кореляційного аналізу встановлено важливі для селекційного процесу зв'язки між якісними і кількісними ознаками у досліджених генотипів. Встановлено, що за проявом асоціації ознак, які визначають фенотип листкової пластинки най- 
більш контрастними порівняно із вихідною формою виявилися 2 мутантні зразки - [Сніжинка (ДМС, 6 год.), мф-1] (К-7392(1)) $\left(r_{s}=0,43\right)$ та [Сніжинка (7 кР)] (К-7402) $\left(r_{s}=0,31\right)$. Висновки. Досліджені кореляційні зв'язки дають можливість проводити добір високопродуктивних генотипів салату листкового на ранніх етапах онтогенезу рослин за асоціацією якісних ознак, що визначають фенотип листкової пластинки. Особливо корисним $€$ встановлений, статистично достовірний кореляційний зв'язок, між інтегральним показником для сукупності якісних ознак “середній індекс для вибірки” та рівнем кількісних ознак “найбільша довжина листка" і “урожайність" $\left(r_{s}=-0,51 \ldots 0,49\right)$, що $є$ важливим для відбору оцінки високопродуктивних генотипів салату листкового. На основі мутантних зразків салату листкового створено новий високопродуктивний сорт Мажор, який перевищив сорт-стандарт Сніжинка за комплексом цінних кількісних ознак. Урожайність нового сорту становить 10,0 т/га при 6,14 т/га у стандарту. Період від масових сходів до товарної стиглості у нового сорту становить 17 діб, у сорту-стандарту Сніжинка до 23 діб.

Ключові слова: салат листковий, листкова пластинка, якісні ознаки, індукований мутагенез, кореляційні зв'язки

Вступ. Останніми роками у світовому виробництві зеленних культур значно збільшився попит на салат листковий, в наслідок чого, намітилося посилення селекційної роботи по даній культурі (FAOSTAT, 2012). Основне завдання вітчизняної селекції салату листкового полягає у виведенні сортів, придатних для вирощування у всіх агрокліматичних зонах країни як у відкритому, так і захищеному грунті (Yakovenko K.I., 2000; Ruchkin O.V., 1999). Для створення сортів даної зеленної культури в основному застосовується гібридизація 3 наступним індивідуальним, груповим і масовим відборами. При створенні більшості сучасних сортів використовується гібридний матеріал. Техніка гібридизації салату листкового досить складна, вона обумовлена будовою і величиною квітки, пристосованої до самозапилення, а також біологією цвітіння (Yakovenko K.I., 2001; Pivovarov V.F., 2000). Для розширення генофонду салату листкового доцільно використовувати метод індукованого мутагенезу як унікальної селекційної технології, яку доцільно використовувати для тих ситуацій, коли необхідно покращити тільки одну важливу ознаку, залишаючи основний геном не зміненим (Franco С.Н., 2015; Grube R.C., 2003; Ohki S. 2012; Okubara P. A., 1994; Sarizam Ş., 2017; Tkalych Yu.V., 2015).

Аналіз останніх досліджень і публікацій з досліджуваної теми. Багато зарубіжних вчених займаються мутагенезом салату, що дає можливість вирішувати проблеми покращення тих чи інших показників цієї культури (Moi V., 2011; Huo H., 2016; Parry M.A. Madgwick, 2009). В селекції використовується як індукований мутагенез, так і спонтанні мутанти, які часто з'являються у популяціях рослин. В США пошук джерел стійкості до несправжньої борошнистої роси проводився серед сортів, селекційних і мутантних ліній, отриманих шляхом $\gamma$-опромінювання. У процесі відбору були виявлені стійкі форми - сорти Grand Rapids, Ice berg і 3 мутантні лінії (Grube R.C., 2005). За даними D. Marcu та ін., найбільшу ефект від дії мутагенних чинників досягається після їх використання для обробки насіння (Delia Marcu, 2012; Wi S.G., 2007). Проте в Україні досліджень за цим напрямом проведено вкрай недостатньо, а корисний потенціал мутагенезу для селекції салату листкового до кінця не визначено і не досліджено.

Мета досліджень - визначити дію мутагенних чинників на формування якісних ознак, які визначають фенотип листкової пластинки та провести порівняльний кореляційний аналіз між проявом якісних і кількісних ознак генотипів салату листкового мутантного походження.

Матеріал і методи досліджень. 3 метою розширення спектру генотипової мінливості салату посівного листкового (Lactuca sativa var. secalina L.) у 2011 році на експериментальній базі Інституту овочівництва і баштанництва НААН був закладений дослід 3 хімічного і фізичного мутагенезу. Як об'єкт досліджень, у досліді використовувався сорт салату листкового Сніжинка селекції Дослідної станції "Маяк” ІОБ НААН. Для отримання мутантних зразків салату листкового повітряно-сухе насіння сорту обробляли речовиною мутагенної дії - диметилсульфатом (ДМС). Дана обробка проводилася шляхом передпосівного занурення у водні розчин препарату у діючій концентрації $0,02 \%$ за різних часових експозиціях обробки (3, 6 і 18 год.). Контроль - насіння намочене у дистильованій воді. У якості фізичного мутагену використовувалося $\gamma$-опромінювання, за допомогою якого проводилася передпосівна обробка повітряно-сухого насіння дозами 7, 1115 кілоРентген (кР). Контроль повітряно-сухе насіння, яке не зазнало $\gamma$ опромінювання. 
Аналіз мутантних зразків салату листкового за особливостями прояву кількісних і якісних ознак проводилося у польових умовах. Польові дослідження закладали за стандартними методиками, які викладено у науково-методичних виданнях: "Сучасні методи селекції овочевих і баштанних рослин” (Gorova T.K., 2001), “Сучасні технології в овочівництві” (Yakovenko K.I., 2001).

При аналізі фенотипу мутантних форм салату листкового була виявлена їх відмінність від вихідних сортових генотипів за асоціацією якісних ознак листкової пластинки, які визначають іiі морфологію, жилкування, форму краю та забарвлення. Для оцінки ступеню прояву якісних ознак даного органу у мутантних генотипів за основу була взята "Методика проведення експертизи сортів салату посівного (Lactuca sativa L.) на відмінність, однорідність і стабільність" Українського інституту експертизи сортів рослин, у якій запропоновано відповідні коди (бали) ступеню прояву 17 якісних ознак листка для визначення апробаційних ознак сортів на BOC-тест (Leschuk N.V., 2007). Серед досліджених якісних ознак - сім, що визначають морфологію листкової пластинки та жилкування (“розсіченість краю листкової пластинки”, “загальна форма листкової пластинки”, “форма верхівки листкової пластинки”. "глянсуватість 3 верх- нього боку листкової пластинки". "пухирчатість листкової пластинки”, “пухирі за розміром на листковій пластинці”, “жилкування листкової пластинки”), чотири, що визначають форму краю листкової пластинки (“хвилястість краю листкової пластинки", "розсіченість краю верхівки листкової пластинки”, “глибина розсіченості краю верхівки листкової пластинки”, “ступінь розсіченості краю верхівки листкової пластинки”), шість, що визначають забарвлення листкової пластинки (“відтінок зеленого забарвлення листкової пластинки”, “інтенсивність забарвлення зовнішніх листків”, “антоціанове забарвлення листкової пластинки”, “інтенсивність антоціанового забарвлення листкової пластинки”, “поширення антоціанового забарвлення листкової пластинки”. “тип поширення антоціанового забарвлення листкової пластинки”). Для проведення варіаційного аналізу якісних ознак, що визначають фенотип листкової пластинки у роботі використовували наступні статистичні показники, запропоновані у роботі (Litun P.P., 2009): коефіцієнт рангової кореляції Спірмана, $r_{s}$; дисперсійний аналіз Фрідмана; коефіцієнт конкордації Кендала, $W$.

Результати досліджень. В результаті індукованого мутагенезу було отримано 8 мутантних зразків, похідних від сорту салату листкового сорту Сніжинка (К-7374) (табл. 1).

Таблиця 1 - Мутантні генотипи салату листкового, одержані в результаті дії різних за природою мутагенних чинників, $2011 \mathrm{p}$.

\begin{tabular}{|c|c|c|c|}
\hline $\begin{array}{l}\text { № } \\
3 / \text { ח }\end{array}$ & $\begin{array}{l}\text { Мутагенний } \\
\text { чинник }\end{array}$ & $\begin{array}{c}\text { Регламент } \\
\text { застосування }\end{array}$ & $\begin{array}{l}\text { Закодована назва мутантного ге- } \\
\text { нотипу }\end{array}$ \\
\hline 1. & \multicolumn{3}{|c|}{ Вихідна форма - сорт Сніжинка (К-7374) } \\
\hline 2. & \multirow{3}{*}{$\gamma$-опромінення } & передпосівна обробка насіння дозою 7 кР & Сніжинка (7) мф-1 (К-7402) \\
\hline 3. & & $\begin{array}{l}\gamma \text {-опромінення } \\
\text { дозою } 11 \text { кР }\end{array}$ & Сніжинка (11) мф-1 (К-7405) \\
\hline 4. & & $\begin{array}{l}\gamma \text {-опромінення } \\
\text { дозою } 15 \mathrm{\kappa}\end{array}$ & Сніжинка (15) мф-1 (К-7410) \\
\hline 5. & \multirow{5}{*}{$\begin{array}{l}\text { Препарат } \\
\text { ДМС }\end{array}$} & \multirow{2}{*}{$\begin{array}{l}\text { передпосівна обробка насіння експозицією } 3 \\
\text { год. }\end{array}$} & Сніжинка (3) мф-1 (К-7388) \\
\hline 6. & & & Сніжинка (3) мф-1 (К-7389) \\
\hline 7. & & \multirow{2}{*}{$\begin{array}{l}\text { передпосівна обробка насіння експозицією } 6 \\
\text { год. }\end{array}$} & Сніжинка (6) мф-1 (К-7392(1)) \\
\hline 8. & & & Сніжинка (6) мф-2 (К-7392(2)) \\
\hline 9. & & $\begin{array}{l}\text { передпосівна обробка насіння експозицією } \\
18 \text { год. }\end{array}$ & Сніжинка (18) мф-1 (К-7396) \\
\hline
\end{tabular}

Аналіз мутантних зразків салату листкового, одержаних від даного сорту проводився на поколінні $\mathrm{M}_{4}$ за умов його вирощування у польових умовах у 2014 році. Мутантний генофонд був представлений лише генотипами, які утворилися в результаті $\gamma$-опромінювання у дозах 7 кР, 11 кР і 15 кР (фізичний мутагенний чинник) і дії препарату ДМС у різних часових експозиціях передпосівної обробки насіння. Генотиповою реакцію даного сорту на дію інших мутагенних речовин позначи- 
лася втратою схожості насіння після його передпосівної обробки за вище означеної концентрацій і експозиціях дії.

У результаті індукованого мутагенезу у сорту Сніжинка (К-7374) найбільшої варіабельності за проявом зазнала ознака “інтенсивність забарвлення зовнішніх листків”. Практично не змінилися за проявом ознаки "розсіченість краю листкової пластинки” i “жилкування листкової пластинки”. Група 37 ознак, що визначають морфологію листкової пластинки та іiі жилкування мали 16 ступенів прояву. Група 34 ознак, які визначають форму краю листкової пластинки відзначилася 9 ступенями прояву. Група 36 ознак, які визначають забарвлення листкової пластинки мала 15 ступенів прояву.
Для оцінки відмінності мутантних форм та вихідної форми за якісними ознаками, що визначають фенотип листкової пластинки у роботі використовувався ранговий дисперсійний аналіз Фрідмана, коефіцієнт конкордації Кендала та коефіцієнт рангової кореляції Спірмена. Порівняння мутантних зразків та вихідної форми проводилося за вищевказаними критеріями через порівняння 3 середніми значеннями ознак в експерименті. Результати розрахунків зведені у таблицю 2. Одержані дані засвідчили відмінність між вихідною формою і похідними від неї мутантними зразками за морфогенезом асоціації ознак, які визначають фенотип листкової пластинки (табл. 2).

Таблиця 2 - Результати обчислення методами непараметричної статистики особливостей прояву асоціації якісних ознак, які визначають морфологію, жилкування, форму краю та забарвлення листкової пластинки мутантних форм, похідних від сорту салату листкового Сніжинка (К-7374)

\begin{tabular}{|c|c|c|c|c|c|c|c|}
\hline \multirow[b]{2}{*}{$\begin{array}{l}\text { № } \\
3 / \Pi\end{array}$} & \multirow[b]{2}{*}{ Мутантний зразок } & \multirow[b]{2}{*}{ № кат } & \multicolumn{4}{|c|}{$\begin{array}{c}\text { Результати рангового } \\
\text { дисперсійного аналізу Фрідмана }\end{array}$} & \multirow{2}{*}{$\begin{array}{l}\text { Коефіцієнт } \\
\text { рангової ко } \\
\text { реляції Спі- } \\
\text { рмена, } r_{s} *\end{array}$} \\
\hline & & & $\begin{array}{c}\text { середній } \\
\text { ранг }\end{array}$ & $\begin{array}{c}\text { сума } \\
\text { рангів, } \\
S_{i}\end{array}$ & $\begin{array}{c}\text { середній } \\
\text { індекс для } \\
\text { вибірки }\end{array}$ & $\begin{array}{c}\text { середньо ква- } \\
\text { дратичне від- } \\
\text { хилення }\end{array}$ & \\
\hline 1. & $\begin{array}{l}\text { Сорт Сніжинка (вихідна } \\
\text { форма) }\end{array}$ & K-7374 & 5,29 & 90,0 & 2,29 & 2,31 & - \\
\hline 2. & Сніжинка (ДМС, 3 год.) & K-7388 & 4,06 & 69,0 & 1,41 & 1,81 & 0,71 \\
\hline 3. & Сніжинка (ДМС, 3 год.) & K-7389 & 4,47 & 76,0 & 1,65 & 1,50 & $\mathbf{0 , 9 2}$ \\
\hline 4. & $\begin{array}{l}\text { Сніжинка (ДМС, } 6 \text { год.), } \\
\text { мф-1 }\end{array}$ & $\begin{array}{c}\mathrm{K}- \\
7392(1)\end{array}$ & 5,56 & 94,5 & 2,76 & 2,44 & 0,43 \\
\hline 5. & $\begin{array}{l}\text { Сніжинка (ДМС, } 6 \text { год.), } \\
\text { мф-2 }\end{array}$ & $\begin{array}{c}\mathrm{K}- \\
7392(2)\end{array}$ & 5,85 & 99,5 & 2,88 & 2,50 & $\mathbf{0 , 6 0}$ \\
\hline 6. & Сніжинка (ДМС, 18 год.) & K-7396 & 4,47 & 76,0 & 1,65 & 1,50 & $\mathbf{0 , 9 2}$ \\
\hline 7. & Сніжинка (7 кР) & K-7402 & 5,21 & 88,5 & 2,47 & 2,30 & 0,31 \\
\hline 8. & Сніжинка (11 кР) & K-7405 & 4,0 & 68,0 & 1,29 & 1,36 & $\mathbf{0 , 7 9}$ \\
\hline 9. & Сніжинка (15 кР) & K-7410 & 6,09 & 103,5 & 2,94 & 2,46 & $\mathbf{0 , 5 9}$ \\
\hline
\end{tabular}


Одним із критеріїв відмінності за інтегральним вираженням блоку ознак у досліджуваної вибірки мутантних форм $є$ порівняння суми рангів $\left(S_{i}\right) 3$ експериментальним значенням критерію $\chi_{\text {експ }}^{2}$ (Parry M.A. Madgwick, 2009). А саме, якщо зу-

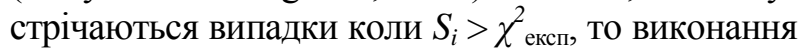
цієї нерівності є доказом наявності мутантних генотипів, відмінних від вихідного сорту. Порівняння суми рангів $\left(S_{i}\right)$ з експериментальним зна-

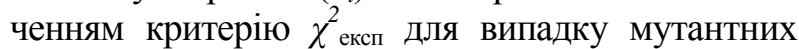
зразків, похідних від сорту Сніжинка (К-7374) за-

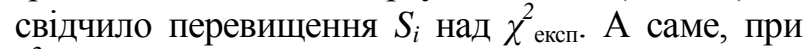
$\chi_{\text {експ. }}^{2}=21,40$, розмах варіювання показника "сума рангів $\left(S_{i}\right)$ " становив 68,0-103,5. Тобто у досліді мали місце суттєві, експериментально доведені, відмінності між мутантними і вихідною формами за досліджуваною асоціацією якісних ознак (табл. 2). При цьому розрахунок коефіцієнту конкордації Кендала $(W=0,155)$ засвідчив наявність незначної узгодженості морфогенетичних процесів, які передували блоку сформованих асоційованих ознак та наявність суттєвої специфічності за ними. Більш виражену оцінку відмінності мутантних генотипів та вихідної форми дали показник “середній індекс для вибірки” дисперсійного аналізу Фрідмана та значення коефіцієнту рангової кореляції Спірмена $\left(r_{s}\right)$. Як свідчать дані таблиці 2 парні значення коефіцієнту рангової кореляції Спірмена $\left(r_{s}\right)$ між вихідною формою і мутантними генотипами варіювали в межах 0,310,92, а показник “Середній індекс для вибірки” варіював в межах 1,29-2,94. Найбільш спорідненими за статистично достовірними значеннями коефіцієнту рангової кореляції Спірмена iз вихідною формою були 6 мутантних зразків: [Сніжинка (ДМС, 3 год.)] (К-7388) $\left(r_{s}=0,71\right)$; [Сніжинка (ДМС, 3 год.)] (К-7389) $\left(r_{s}=0,92\right)$; [Сніжинка (ДМС, 6 год.), мф-2] (К-7392(2)) $\left(r_{s}\right.$ $=0,60)$; [Сніжинка (ДМС, 18 год.)] (К-7396) $\left(r_{s}\right.$ $=0,92) ;$ [Сніжинка (11 кР)[ К-7405 $\left(r_{s}=0,79\right)$; [Сніжинка $\left(15\right.$ кР)] К-7410 $\left(r_{s}=0,59\right)$. При цьому, варіювання середніх індексів вибірки усіх мутантних зразків знаходилися в межах похибки значення середнього індексу, який відповідає сорту Сніжинка (К-7374). Менш спорідненими виявилися два мутантні зразки [Сніжинка (ДМС, 6 год.), мф-1] (К-7392(1)) $\left(r_{s}=0,43\right)$ та [Сніжинка $\left(7\right.$ кР)] (К-7402) $\left(r_{s}=0,31\right)$.Після встановлення особливостей прояву якісних ознак, що визначають фенотип листкової пластинки був проведений кореляційний аналіз між цими ознаками та кількісними господарськоцінними ознаками, які, по суті, є відображенням морфо-фізіологічних показників росту рослин як вихідної, так і мутантних форм салату листкового. Всього в кореляційному аналізі були задіяні 6 кількісних ознак: “висота розетки рослин”; “ширина розетки рослин”, “кількість листків на одній рослині”; “найбільша довжина листка”; “найбільша ширина листка”; “урожайність”. Інтегральним критерієм варіабельності якісних ознак для певного зразку салату листкового був показник “середній індекс для вибірки". Під час проведення кореляційного аналізу цей показник порівнювався 3 відповідними кількісними ознаками рослин цього ж зразку салату листкового. Для кореляційного аналізу використовувалися не тільки мутантні зразки, але й вихідна форма, від яких вони були похідні. Тобто при формуванні первинної бази даних для проведення кореляційного аналізу до блоку порівняльних відповідних показників якісних і кількісних ознак мутантних зразків були додані відповідні дані по вихідній формі. Формування бази даних кількісних ознак проводилося за результатами трьохрічних (2012-2014 років) біометричних вимірювань у польових умовах показників росту рослин салату листкового як вихідних форм, так і похідних від них мутантних зразків покоління $\mathrm{M}_{2}-\mathrm{M}_{4}$. Дані щодо особливостей прояву кількісних ознак мутантних зразків салату листкового відображені в роботі (Kondratenko S.I., 2018).

Результати кореляційного аналізу засвідчили, що для групи філогенетично споріднених генотипів, яка була утворена сортом Сніжинка (К-7374) та похідними від нього 8 мутантними генотипами статистично достовірними виявилися значення коефіцієнту рангової кореляції Спірмена $\left(r_{s}\right)$ між показником "середній індекс для вибірки” та трьома кількісними ознаками “висота розетки рослин” $\left(r_{s}\right.$ $=0,552)$, “найбільша довжина листка" $\left(r_{s}=0,485\right)$, “урожайність" $\left(r_{s}=-0,510\right)$.

Для групи філогенетично споріднених генотипів, яка утворена сортом Сніжинка (К-7374) та похідними від нього 8 мутантними генотипами статистично достовірними виявилися значення коефіцієнту кореляції між показником “Середній індекс для вибірки” та трьома кількісними ознаками “Висота розетки рослин" $\left(r_{s}=0,552\right)$, “Найбільша довжина листка" $\left(r_{s}=0,485\right)$, "Урожайність" $\left(r_{s}=-0,510\right)$.

У 2015 році на кваліфікаційну експертизу до системи державного сортовипробування було передано 1 сорт салату листкового мутантного походження Мажор (рис. 1). 


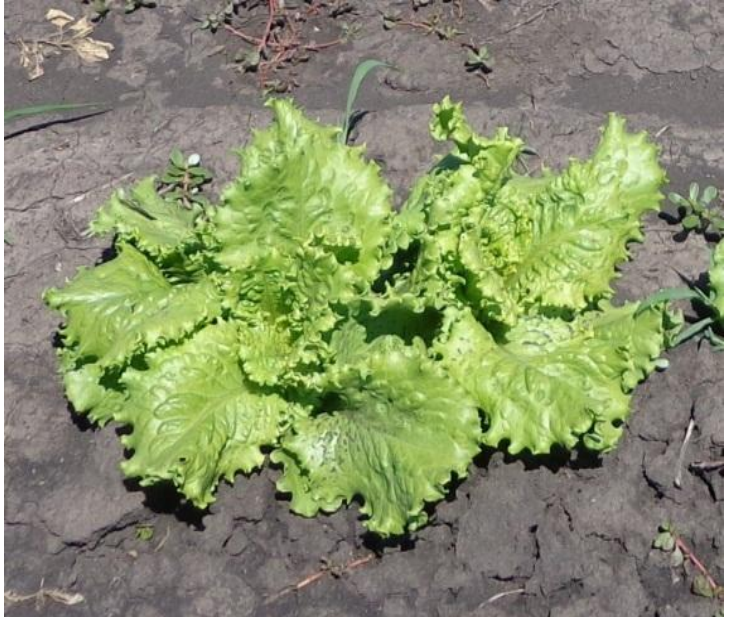

Рисунок 1. Зовнішній вигляд листкової розетки рослини у період господарської придатності сорту салату листкового мутантного походження Мажор

Сорт створений на основі мутантного зразку [Сніжинка (ДМС, 18 год.)] (К-7396), який одержано у 2011 році в результаті передпосівної обробки хімічною речовиною мутагенної дії ДМС (концентрація - 0,02\%, експозиція дії - 18 год.) насіння сорту Сніжинка (К-7374).

Схема створення сорту складалася 3 наступних етапів: добір індивідуальних відборів мутантних генотипів рослин за комплексом якісних і кількісних ознак, відмінних від вихідних форм у розсаднику покоління $\mathrm{M}_{1}(2011$ р.); оцінка і розмноження індивідуальних відборів у розсадниках мутантного покоління $\mathrm{M}_{2}$ i $\mathrm{M}_{3}$ на вирівняність i однорідність прояву якісних ознак, відбір константних форм за комплексом господарсько-цінних кількісних ознак (2012-2013рр.); оцінка мутантних ліній за комплексом господарсько-цінних ознак у розсаднику конкурсного сортовипробування (2014-2015 рр.).

Сорт середньостиглий, 3 тривалістю періоду діб від масових сходів до товарної стиглості 17 діб, урожайністю 10,03 т/га (у сорту-стандарту Сніжинка (К-7344) - 6,2 т/га), посухостійкістю на рівні 7 балів, вмістом сухої речовини - 6,6 \% (у стандарту $-6,2 \%)$, загального цукру $-1,12 \%$ (у стандарту $0,7 \%$ ), вітаміну С - 24,39 мг/100 г (у стандарту $20,62 \mathrm{мг} / 100$ г).

Розрахована економічна ефективність від впровадження створеного сорту Мажор, який рекомендується для вирощування у відкритому грунті мала наступні складові собівартості: фонд заробітної плати, матеріальні витрати (паливномастильні матеріали, витрати на зрошення, амортизаційні відрахування, загальновиробничі та загальногосподарські витрати. Економічну ефекти- вність розраховували в середньому за 2-3 роки, впродовж яких тривало сортовипробування. Загальні витрати на вирощування нового сорту салату листкового у відкритому грунті на 1 га посівної площі дещо перевищували стандарт за рахунок збільшення витрат на збирання і перевезення додаткової продукції і становили 112,08 тис. грн. (табл. 3).

Таблиця 3 - Економічна ефективність і рентабельність вирощування нового сорту салату листкового Мажор за результатами конкурсного сортовипробування, середнє за 2014-2015 pp.

\begin{tabular}{|l|c|c|}
\hline \multirow{1}{*}{ Показник } & \multicolumn{2}{|c|}{ Сорт салату листкового } \\
\cline { 2 - 3 } Пніжинка, st & Мажор \\
\hline Площа, га & 1 & 1 \\
\hline $\begin{array}{l}\text { Урожайність, } \\
\text { т/га }\end{array}$ & 6,38 & 10,03 \\
\hline $\begin{array}{l}\text { Виручка від } \\
\text { реалізації * } \\
\text { тис. грн. / га }\end{array}$ & 159,50 & 271,50 \\
\hline $\begin{array}{l}\text { Витрати на ви- } \\
\text { робництво, } \\
\text { тис. грн. / га }\end{array}$ & 77,50 & 112,08 \\
\hline $\begin{array}{l}\text { Економічний } \\
\text { ефект, } \\
\text { тис. грн. / га }\end{array}$ & - & 77,42 \\
\hline $\begin{array}{l}\text { Рівень рента- } \\
\text { бельності, \% }\end{array}$ & 106 & 142 \\
\hline $\begin{array}{l}\text { Примітка. * - За середніми цінами } 2018 \text { р. } \\
\text { (25,0 грн. / кг). }\end{array}$ \\
\hline
\end{tabular}

Витрати на вирощування сортів салату листкового та економічну ефективність розраховували згідно технологічних карт, розроблених в ІОБ НААН, за розцінками 2018 року Sabluk P.T., Mazorenko D.I., Maznev G.E. at et. (2004). [23]. У розрахунках економічної ефективності вирощування сортів прийнято фактичні витрати на 1 га площі. За розрахунковими показниками, рентабельність вирощування сорту Мажор становила $142 \%$, економічний ефект - 77,42 грн./га. Собівартість продукції новоствореного сорту зменшилася на $25 \%$ у порівнянні зі стандартом і становила 10,3 тис. грн./т.

У розрахунках економічної ефективності вирощування сорту прийнято фактичні витрати на 1 га площі.

Висновки. Як свідчать одержані дані найбільш ефективним на сорті Сніжинка (К-7374) виявився препарат ДМС, передпосівна обробка на- 
сіння яким індукувала формування 5 мутантних зразків, 3 мутантні зразки були отримані в результаті передпосівної обробки насіння $\gamma$ опромінюванням у різних дозах. Серед 5 мутантних генотипів, одержаних в результаті обробки препаратом ДМС, один мав середній рівень кореляційного зв'язку із вихідною формою $\left(0,3<r_{s}<\right.$ $0,6)$, чотири мали сильний зв'язок $\left(r_{s}>0,6\right)$. За проявом асоціації ознак, що визначають фенотип листкової пластинки найбільш контрастними порівняно із вихідною формою виявилися 2 мутантні зразки - [Сніжинка (7 кР)] (К-7402) і [Сніжинка (ДМС, 6 год.), мф-1] (К-7392(1)).

Досліджені кореляційні зв'язки дають можливість у подальшій селекційній роботі проводити добір високопродуктивних генотипів салату листкового на ранніх етапах онтогенезу рослин за асоціацією якісних ознак, що визначають фенотип листкової пластинки. Усі виявлені значення коефіцієнту рангової кореляції Спірмена $\left(r_{s}\right)$ відносилися до діапазону середніх за силою кореляційних зв'язків. Особливо корисним для подальшої селекційної роботи $є$ виявлені кореляційні зв'язки між непараметричним критерієм, що визначає відмінність фенотипу листкової пластинки за асоціацією якісних ознак та трьома кількісними ознаками, які визначають структуру урожайності рослин - "Найбільша довжина листка", "Кількість листків на одній рослині" і "Урожайність”.

\section{References}

Gorova, T. K., Yakovenko, K. I. (Eds). (2001). Suchasni metody selektsiyi ovochevykh i bashtannykh kultur [Modern methods of selection of vegetable and melon cultures]. Kharkiv: Osnova. 432 p. [in Ukrainian].

Grube, R. C., Brennan, E. B., Ryder, E. J. (2003). Characterization and genetic analysis of a lettuce (Lactuca sativa L.) mutant, weary, that exhibits reduced gravitropic response in hypocotyls and inflorescence stems. Journal of Experimental Botany. V. 54: 385. P. 1259-1268. [in English].

Grube, R. C., Ochoa, O. E. (2005). Comparative genetic analysis of field resistance to downy mildew in lettuce the cultivars "Grand Rapids" and "Ice berg". Euphytica. V. 142. P 205215. [in English].

Delia Marcu, Victoria Cristea, Liviu Daraban. (2012). Dose-dependent effects of gamma radiation on lettuce (Lactuca sativa var. capitata) seedl- ings. International Journal of Radiotion Biology. October 2012. P. 219-223. doi.org/10.3109/09553002.2013.734946.

Huo, H., Henry, I. M., Coppoolse, E. R. (2016). Rapid identification of lettuce seed germination mutants by bulked segregant analysis and whole genome sequencing. The Plant Journal. Vol. 88/3. doi.org/10.1111/tpj.13267

Kondratenko, S. I., Mitenko, I. M., Krutko, R. V. at el. (2018). Adaptyvnyy potentsial henofondu salatu posivnoho lystkovoho, stvorenoho metodom indukovanoho mutahenezu na osnovi vitchyznyanoho sortu Velmozha. [Adaptive potential of the gene pool of leaf lettuce, created by the method of induced mutagenesis on the basis of the domestic varieties Velmozha]. № 2 (72). Retrived from

http://journals.nubip.edu.ua/index.php/Dopovidi/ar ticle/view/10641/9358 [in Ukrainian].

Leschuk, N. V. (2007). Metodyka provedennya ekspertyzy sortiv salatu posivnoho (Lactuca sativa L.) na vidminnist, odnoridnist i stabilnist. [Method of conducting examination of varieties of sown lettuce (Lactuca sativa L.) for difference, homogeneity and stability]. Protection of rights to plant varieties: official bulletin. V. 3. Part 2/2007. P. 366-379. [in Ukrainian].

Litun, P. P., Kirichenko, V. V., Petrenkova, V. $P$. at el. (2009). Systemnyy analiz v selektsiyi polovykh kultur: navchalnyy posibnyk [System analysis in field crop selection: tutorial]. Kharkiv: The Plant Production Institute nd. a. V. Ya. Yuryev of NAAS. 351 p. [in Ukrainian].

Moi V. (2011). Mutations in lettuce improvement. International Journal of Plant Genomics. Article ID 723518, 7 pages. doi: $10.1155 / 2011 / 723518$

Ohki, S. and Hatashita, M. (2012). Mutation breeding by ion beam in lettuce (Lactuca sativa L.) using an in vitro regeneration. Research and Development Department Proc, 7th ISHS on In Vitro Culture and Horticultural Breeding / Ed. D. Geelen. Acta Hort. V. 961, P. 285-290. [in English].

Okubara, P. A., Anderson, P. A., Ochoa, O. E. et al. (1994). Mutants of downy mildew resistance in Lactuca sativa (lettuce). Genetics. V. 137. № 3. P. 867-874. [in English].

Parry, M. A. Madgwick, P. J. Bayon, C. et al. (2009). Mutation discovery for crop improvement. Journal of Experimental Botany. V. 60. P. 2817 2825. [in English].

Pivovarov, V. F., Dobrutskaya, E. G. (2000). Ekologicheskiye osnovy selektsii i semenovodstva 
ovoshchnykh kul'tur. [Ecological basis for breeding and seed production of vegetable crops]. Moskva. 197 p. [in Russiun].

Ruchkin, O. V. (1999). Napryamok rozvytku vyrobnytstva ta realizatsiyi produktsiyi ovochivnytstva i bashtannytstva $\mathrm{v}$ Ukrayini $\mathrm{v}$ umovakh rynku. [The direction of development and production of vegetable and melon products in Ukraine in the market conditions]. Vegetables and Melons Growing. № 44. P. 3-7. [in Ukrainian].

Sabluk, P. T., Mazorenko, D. I., Maznev, G. E. at et. (2004). Tekhnolohichni karty ta vytraty na vyroshchuvannya sil's'kohospodars'kykh kul'tur [Technological maps and costs of growing crops]. Kharkiv: KNTUA them. P. Vasilenko. 351 p. [in Ukrainian].

Sarizam, Ş., Kantoğlu, K. Y., Ş. Ellialtioğlu, Ş. (2017). Determination of Effective Mutagen Dose for Lettuce (Lactuca sativa var. longifolia cv. Cervantes) Seeds. Eurasian Journal of Agricultural Research. Vol. 1. Issue 2. P. 108-114. [in English].

Tkalych, Yu. V., Korniyenko, S. I., Kondratenko, S. I. et al. (2015). Vykorystannya g-oprominennya nasinnya $\mathrm{v}$ selektsiyi salatu posivnoho. [Use of $\gamma$ irradiation of seeds in the breeding of sown lettuce]. Vegetables and Melons Growing. № 61. P. 289-300. [in Ukrainian].
FAOSTAT. Lettuce and chicory crop production. Food Agric Organ Stat Div. (2012). Retrived from: http://faostat3.fao.org/faostatgateway/go/to/search/lettuce/E. [in English].

Franco, C. H., Santos, H. M., Silva, L. P. et al. (2015). Mutagenic Potential of Lettuce Grown from Irradiated Seeds. Scientia Horticulturae. V. 182. P. 27-30. [in English].

Wi, S. G., Chung, B. Y., Kim, J. S. et al. (2007). Effects of gamma irradiation on morphological changes and biological responses in plants. 2007. Micron. V. 38. P. 553-564. [in English].

Yakovenko, K. I. (2000). Ovochivnytstvo Ukrayiny na porozi XXI stolittya. [Vegetable Ukraine on the threshold of the XXI century]. Bulletin of Agrarian Science. № 8. P. 21-22. [in Ukrainian].

Yakovenko, K. I. (Eds). (2001). Metodyka doslidnoyi spravy $\mathrm{v}$ ovochivnytstvi i bashtannytstvi [Methodology of experimental work in vegetable and melon]. Kharkiv: Osnova. 369 p. [in Ukrainian].

Yakovenko, K. I. (Eds). (2001). Suchasni tekhnolohy $\mathrm{v}$ ovochivnytstvi [Modern technology in vegetable growing]. Kharkiv: IOB UAAN. 128 p. [in Ukrainian]. 